\title{
UNJUK KERJA MOTOR BRUSHLESS DIRECT CURRENTAXIAL FLUX 3 FASA STATOR GANDA TERHADAP PERBEDAAN JENIS KAWAT ENAMEL PADA KUMPARAN STATOR
}

\author{
Performance Brushless Direct Current Motoraxial Flux 3 Phase Double Stator on the \\ Difference of Enamel Wire Type in Stator Coil
}

\author{
M. Faisal Alif Hidayat ${ }^{1}$, Widyono $\mathrm{Hadi}^{2}$,Arizal Mujibtamala Nanda Imron ${ }^{3}$ \\ 1) Jurusan Teknik Elektro, Universas Jember. \\ ${ }^{2.3}$ Staf Pengajar Jurusan Teknik Elektro, Fakultas Teknik, Universitas Jember \\ JI. Kalimantan No. 37, Kampus Tegalboto, Jember, Jawa Timur, 68121, Indonesia, INDONESIA \\ Email: faisalalif02@gmail.com, widyono.hadi1961@gmail.com, arizal.tamala@unej.ac.id
}

\begin{abstract}
ABSTRAK
Pada dewasa kini, teknologi semakin berkembang pesat dalam pemenuhan kebutuhan masyarakat.Dalam perkembangan teknologi tersebut salah satunya dilakukan penelitian pada motor DC utamanya motor jenis BLDC guna mengembangkan dan memperbaiki unjuk kerja yang ada. Penelitian unjuk kerja dilakukan menggunakan motor Brushless Direct CurrentAxial Flux 3 fasa stator ganda. Pengujian dilakukan dengan dua kawat enamel yang berbeda jenis (Hellenic dan Supreme) 0,3 mm. Setiap kumparan pada kawat enamel memiliki panjang 13,5 $\mathrm{m}$ yang terpasang pada stator. Dari hasil pengujian dengan menggunakan perbedaan jenis kawat enamel Hellenic dan Supreme, didapat perbedaan pada kecepatan maupun torsi yang dihasilkan. Untuk motor Brushless Direct Current kawat enamel Hellenic lebih baik karena memiliki kuat torsi yang lebih tinggi $(0,336 \mathrm{Nm})$ dengan perubahan panas yang rendah jika dibandingkan dengan kawat enamel Supreme $(0,24 \mathrm{Nm})$ dengan perubahan panas yang tinggi. Diketahui perubahan resistansi pada kawat enamel berubahsignifikan saat pengujian berulang yang dipengaruhi perubahan suhu..
\end{abstract}

Kata kunci: Unjuk Kerja, Brushless Direct Current Axial Flux, Kumparan Stator, Kawat Enamel.

\begin{abstract}
Nowadays, technology is growing rapidly in meeting the needs of society. In this technological development, one of the researches was carried out on DC motors, especially BLDC type motors, in order to develop and improve existing performance. The performance research was carried out using a dual stator 3 phase Brushless Direct Current Axial Flux motor. The test was carried out with two enamel wires of different types (Hellenic and Supreme) $0.3 \mathrm{~mm}$. Each coil of enameled wire having a length of $13.5 \mathrm{~m}$ is attached to the stator. From the test results using different types of Hellenic and Supreme enamel wires, it was found that the difference in speed and torque was produced. For the Brushless Direct Current motor Hellenic enamel wire is better because it has a higher torque strength $(0.336 \mathrm{Nm})$ with a lower heat change when compared to Supreme enamel wire $(0.24 \mathrm{Nm})$ with high heat changes. It is known that the change in resistance in enameled wire changes significantly when the test is repeated due to temperature changes..
\end{abstract}

Key words: Performance, Brushless Direct Current Axial Flux, Stator Coils, Enameled Wire.

\section{PENDAHULUAN}

Pada dewasa kini, teknologi semakin berkembang pesat dalam pemenuhan kebutuhan masyarakat.Dalam perkembangan teknologi tersebut salah satunya dilakukan penelitian pada motor DC utamanya motor jenis BLDC guna mengembangkan dan memperbaiki unjuk kerja yang ada.. Beberapa peralatan mesin DC yang terus dilakukan pengembangan yaitu berupa motor BLDC (BrushlessDirect current Motor). Kelebihan motor brushless dibandingkan motor brush adalah daya tinggi terhadap torsi tinggi, kecepatan tinggi, kontrol elektronik, dan perawatan yang rendah. 
Motor fluks aksial merupakan salah satu jenis penggunaan aplikasi dari desain mesin-mesin listrik yang memiliki arah aliran fluks secara aksial seperti halnya motor pada sepeda listrik. Hal ini tidak menutup sebuah kemungkinan seiring dengan perkembangan zaman, perkembangan motor BLDC ini terus dilakukan Dikarenakan banyaknya penggunaan motor BLDC dalam tipe aksial maka dilakukanlah penelitian dengan menggunakan aksial fluks.

Sehingga pada penelitian ini akan dirancang sebuah motor brushless direct current axial flux 3 fasa stator ganda dengan magnet neodymium pada rotor motor. Motor yang telah dibuat menggunakan double stator dan stator tunggal. Dari hasil tersebut dapat diketahui bahwa dengan penambahan stator ganda maka dapat menambah torsi putaran $(\mathrm{Nm})$ pada motor BLDC.Karena motor listrik dengan fluks magnetik axial ini dapat didesain coreless (tanpa armatur) sehingga sesuai dengan prinsip konstruksi motor brushless direct current. Selanjutnya dalam perbandingan unjuk kerja, dilakukan penggantian pada kawat enamel pada kumparan dengan perbedaan jenis kawat enamel sehingga didapatkan hasil penelitian yang objektif.

\section{Motor Listrik}

Motor listrik termasuk kedalam kategori mesin listrik dinamis dan merupakan sebuah perangkat elektromagnetik yang mengubah energi listrik menjadi energi mekanik. Energi mekanik ini digunakan untuk, misalnya, memutar impeller pompa, fan atau blower, menggerakan kompresor, mengangkat bahan, dll di industri dan digunakan juga pada peralatan listrik rumah tangga (seperti: mixer, bor listrik,kipas angin). Motor listrik kadangkala disebut "kuda kerja" nya industri, sebab diperkirakan bahwa motor-motor menggunakan sekitar $70 \%$ beban listrik total di industri.[3]

Mekanisme kerja untuk seluruh jenis motor listrik secara umum sama, yaitu arus listrik dalam medan magnet akan memberikan gaya, Jika kawat yang membawa arus dibengkokkan menjadi sebuah lingkaran/loop, maka kedua sisi loop, yaitu pada sudut kanan medan magnet, akan mendapatkan gaya pada arah yang berlawanan. Dan pasangan gaya menghasilkan tenaga putar/ torsi untuk memutar kumparan. Motor-motor memiliki beberapa loop pada dinamonya untuk memberikan tenaga putaran yang lebih seragam dan medan magnetnya dihasilkan oleh susunan elektromagnetik yang disebut kumparan medan.

Saat ini yang banyak digunakan pada kegiatan sehari hari adalah motor DC. Motor DC tersedia dalam banyak ukuran, namun penggunaannya pada umumnya dibatasi untuk beberapa penggunaan daya rendah hingga sedang, seperti peralatan mesin dan rolling mills, sebab sering terjadi masalah dengan perubahan arah arus listrik mekanis pada ukuran yang lebih besar. Juga, motor tersebut dibatasi hanya untuk penggunaan di area yang bersih dan tidak berbahaya sebab resiko percikan api pada sikatnya. Motor DC juga relatif mahal dibanding motor AC.

\section{Motor Brushless DC}

Motor Brushless DC (BLDC) merupakan salah satu jenis motor sinkron yang semakin banyak digunakan di banyak aplikasi karena efisien, bebas perawatan dan rasio daya terhadap beban yang baik. Namun pada pengoperasiannya motor BLDC memerlukan sensor posisi rotor [4].

Prinsip kerja dari motor BLDC memiliki konstruksi yang berbeda dengan motor dc pada umumnya, dimana motor ini memiliki tiga fasa yang bebeda sehingga masingmasing fasa memiliki sudut sebesar $120^{\circ}$, sehingga motor BLDC menggunakan halleffect yang digunakan untuk mendeteksi posisi dimana rotor berada dengan menggunakan signal dari komutasi motor.[2]. Dengan menggunakan magnet permanen, tidak ada energi listrik yang diperlukan untuk menggairahkan medan, sehingga meningkatkan efisiensi, kepadatan torsi, dan kepadatan daya motor [2].

Setiap motor BLDC memiliki dua bagian utama, rotor (bagian berputar) dan stator (bagian stasioner). Bagian penting lainnya dari motor adalah gulungan stator dan magnet rotor. Rotor merupakan bagian pada motor yang berputar karena adanya gaya elektromagnetik dari stator, dimana pada motor BLDC bagian rotor berbeda dengan rotor yang ada pada motor DC konvensional dimana hanya tersusun dari satu buah elektromagnet yang berada diantara brushes (sikat) yang terhubung pada dua buah motor hingga delapan pasang kutub magnet permanen yang saling direkatkan menggunakan semacam perekat dan tidak ada brushes-nya..

Stator merupakan bagian pada motor yang diam/statis dimanafungsinya adalah sebagai medan putar motor untuk memberikan gaya elektromagnetik pada rotor sehingga motor dapat berputar. Akibat arus 
yang melewati kumparan pada stator maka akan timbul medan magnet[3].

\section{Kecepatan Motor}

Kecepatan motor didapatkan dari fungsi gerak pada rotor sehingga dapat menggerakkan sumbu penghubung antar motor dan stator. Fungsi dari kecepatan (misalnya dalam satuan metrik Nm RPM), gesekan dinamis karena gesekan kental bantalan bola, serta untuk arus eddy dalam stator berasal oleh Medan magnet berputar magnet.[1]Sehingga untuk mengetahui nilai kecepatan yang ada pada motor secara teoritis maka dapat menggunakan rumus persamaan berikut.

$$
n r=\frac{\sqrt{3} \cdot I a \cdot E a \cdot 60}{2 \pi \cdot T}
$$

Keterangan :

$n r=$ Kecepatan motor (rpm)

$I a=$ Arus Motor $(\mathrm{A})$

$\mathrm{Ea}=$ Tegangan Motor $(\mathrm{V})$

$T=$ Torsi Motor $(\mathrm{Nm})$

\section{Torsi Motor}

Torsi dalam fisika, juga disebut momen atau momen gaya, adalah bentuk ekuivalen rotasi dari gaya linear. Konsep torsi diawali dari kerja Archimedes dengan alat peraga tuas. Secara umum, torsi dapat dianggap sebagai gaya rotasi. Analog rotasi dari gaya, masa, dan percepatan adalah torsi, momen inersia dan percepatan sudut. Gaya yang bekerja pada tuas, dikalikan dengan jarak dari titik tengah tuas, adalah torsi.[10].Sehingga untuk mengetahui nilai torsi yang ada digunakan rumus persamaan berikut.

Keterangan

$$
T=\frac{P}{\omega}
$$

$T=$ Torsi motor $(\mathrm{Nm})$

$\mathrm{P}=$ Daya Motor (Watt)

$\omega=$ Kecepatan sudut (RPS)

Persamaan lain yang dapat digunakan dalam perhitungan torsi yaitu dapat menggunakan hasil perkalian gaya yang didapat pada mengenai gaya putar motor dengan lengan momen atau jari-jari rotor sehingga dapat dinyatakan dengan rumus berikut.

Keterangan :

$$
T=F \times r
$$

$\mathrm{T}=$ Torsi motor $(\mathrm{Nm})$

$\mathrm{F}=$ Gaya tarik menarik dan tolak menolak

$(\mathrm{N})$

$$
r=\text { jari }- \text { jari rotor }(m)
$$

\section{Gaya Putar Motor}

Gaya tolak menolak magnet terjadi pada saat magnet dengan kutub yang sejenis atau senama saling didekatkan. Dua kutub magnet $U$ atau dua kutub magnet $S$ yang saling berdekatan akan saling tolak menolak. Magnet permanen memiliki medan magnet (B).[2] Sesuai dengan hukum Coulumb yang menyatakan bahwa besarnya gaya tolakmenolak atau gaya tarik-menarik antara kutub-kutub magnet, sebanding dengan kuat kutubnya masing-masing dan berbanding terbalik dengan kuadrat jaraknya. ${ }^{[1]}$ Untuk menentukan gaya tolak menolak pada magnet maka dapat digunakan rumus berikut:

$$
F=k \cdot \frac{m 1 \cdot m 2}{r^{2}}
$$

Keterangan :

$\mathrm{F}=$ Gaya tarik menarik/ tolak menolak (N)

$r=$ Jarak/gap antara magnet dan besi kumparan (meter)

$\mathrm{m} 1=$ kuat kutub magnet permanen (A.m)

$\mathrm{m} 2$ = kuat kutub magnet kumparan (A.m)

$\mathrm{k}=10^{7}$ (Weber/A.m)

Dalam menentukan kuat kutub magnet antara magnet permanen dengan kuat kutub pada kumparan memiliki rumus yang sama sesuai dengan hukum Gauss yaitu dengan mengalikan intensitas medan magnet $(H)$ dengan luas penampang $(A)$ dari magnet tersebut

$$
m_{1}=(B \times 10000) \times A
$$

Keterangan:

$m_{1}=$ Kuat kutub magnet permanen

$\mathrm{H}=$ Intensitas medan magnet

$B=$ Rapat garis gaya magnet

(2)

$A=$ Luas penampang magnet

Sedangkan dalam kumparan juga memiliki medan magnet ketika dia aktif dimana pada rumus diatas dilambangkan dengan $m_{2}$. Untuk menentukan kuat kutub magnet pada kumparan dapat diketahui dengan persamaan:

$$
m_{2}=\left(\frac{N \cdot I}{l}\right) \cdot A
$$

Keterangan:

$m_{2}=$ Kuat kutub magnet kumparan

$\mathrm{N}=$ Jumlah kumparan

$\mathrm{I}=\operatorname{Arus}(\mathrm{A})$

I = panjang kumparan $(\mathrm{m})$ 


\section{Magnet Permanen ( Neodymium)}

Magnet neodymium merupakan magnet tetap yang paling kuat.Neodymium adalah kedua yang paling melimpah dari unsur tanah jarang (setelah cerium) yang hampir melimpah seperti tembaga. Hal ini ditemukan dalam mineral yang mencakup semua mineral lantanida, seperti monasit dan bastnasite.Magnet neodymium (juga dikenal sebagai NdFeB, NIB, atau magnet $\mathrm{Neo}$ ).

\section{Kawat Tembaga Enamel}

Kawat Enamel terbuat dari tembaga yang memiliki konduktivitas panas dan listrik yang baik.Selain itu unsur ini memiliki korosi yang cepat sekali.Tembaga murni sifatnya halus dan lunak, dengan permukaan berwarna jingga kemerahan. Kawat enamel yang banyak dijumpai di pasaran lokal adalah kawat buatan Indonesia (PT. Sucaco, Tbk) dan buatan Jerman (Hellenic Cables, $S A)$. Adapun buatan Malaysia dan China (Ningbo Jintian New Material Co, Ltd) tidak semua toko menjualnya.

Kawat produksi PT Sucaco ini ada beberapa jenis diantaranya PVF (polyvinyl Formal) yang cocok untuk electricity meter, UEW (polyurethane), untuk alat-alat rumah tangga dan lainnya, SBUEW (polyurethane self bonding), untuk alat-alat rumah tangga, PEW (polyester), untuk alat-alat rumah tangga, motor, tranformator dll, PEWN (polyester nylon), untuk pompa air, blender, mixer, motor, tranformator, ignition coil, magnetic coil, EIW (polyesterimide), untuk alat-alat rumah tangga, motor, transformator, magnetic coil, PEW Al (polyester poliamideimide), untuk transformator, ignition coil. Kawat enamel lainnya yaitu produksi Hellenic Cable S.A. Jenis-jenisnya terdiri dari Adomin, Enoflex-B, Enoflex-F, Enoflex 180, Enoflex-H, Idiotherm, Mediotherm, Politherm, Enobond 180, Idiobond, Mediobond 200.[9] Aproksimasi linear dapat dikembangkan untuk aproksimasi resistansi dengan suhu (R-T).Acuan nilai untuk perubahan konduktivitas thermal kawat enamel sesuai dengan tabel 1 berikut.
Tabel 1. Daftar Thermal Conductivity pada beberapa bahan[7].

\begin{tabular}{|c|c|c|}
\hline \multirow{2}{*}{ Materials } & \multicolumn{2}{|c|}{ Thermal Conductivity } \\
\hline & $\begin{array}{c}\mathrm{Cal} / \mathrm{sec} / \mathrm{cm}^{2} / \\
(\mathrm{C} / \mathrm{cm})\end{array}$ & $\begin{array}{c}\mathrm{J} / \mathrm{sec} / \mathrm{cm}^{2}(\mathrm{C} / \\
\mathrm{cm})\end{array}$ \\
\hline \multicolumn{3}{|l|}{ NONMETALS } \\
\hline Gypsum & 0,0031 & 0,013 \\
\hline $\begin{array}{c}\text { Zinc phosphate } \\
\text { cement }\end{array}$ & 0,0028 & 0,012 \\
\hline Composite resin & 0,0026 & 0,011 \\
\hline Porcelain & 0,0025 & 0,010 \\
\hline Enamel & 0,0022 & 0,0092 \\
\hline Dentin & 0,0015 & 0,0063 \\
\hline $\begin{array}{c}\text { Zinc oxide- } \\
\text { eugenol cement }\end{array}$ & 0,0011 & 0,0046 \\
\hline Arcylic Resin & 0,0005 & 0,0021 \\
\hline Beeswax & 0,00009 & 0,0004 \\
\hline
\end{tabular}

Pada tabel diatas dapat diketahui untuk nilai koefisien dari konduktivitas thermal dalam $\mathrm{C}$ yaitu sebesar $0,002{ }^{\circ} \mathrm{C} / \mathrm{cm}$. Sehingga nilai koefisien tersebut dapat digunakan sebagai perhitungan teori pembanding yang digunakan untuk membandingkan perhitungan hasil praktik maupun dengan hasil teori.

$$
(T)=R\left(T_{0}\right)[1+\alpha \Delta T]
$$

Keterangan :

$R(T)$ = aproksimasi dari resistan pada suhu $\mathrm{T}$

$R\left(T_{0}\right)=$ resistansi pada suhu $T_{0}$

$\Delta \mathrm{T} \quad=\mathrm{T}-\mathrm{T}_{0}$

$\alpha \quad=$ perubahan fraksi dalam resistansi.

Resistansi atau nilai hambatan dalam sebuah kawat penghantar dapat terpengaruh oleh perubahan suhu lingkungannya.[8] Dikarenakan $\mathrm{Hal}$ tersebut kawat tembaga yang digunakan juga dipengaruhi oleh suhu lingkungan dan kuat kerja kawat yang digunakan sebagai kawat penghantar yang digunakan sebagai koil tersebut. 


\section{METODE PENELITIAN}

Flowchart Diagram

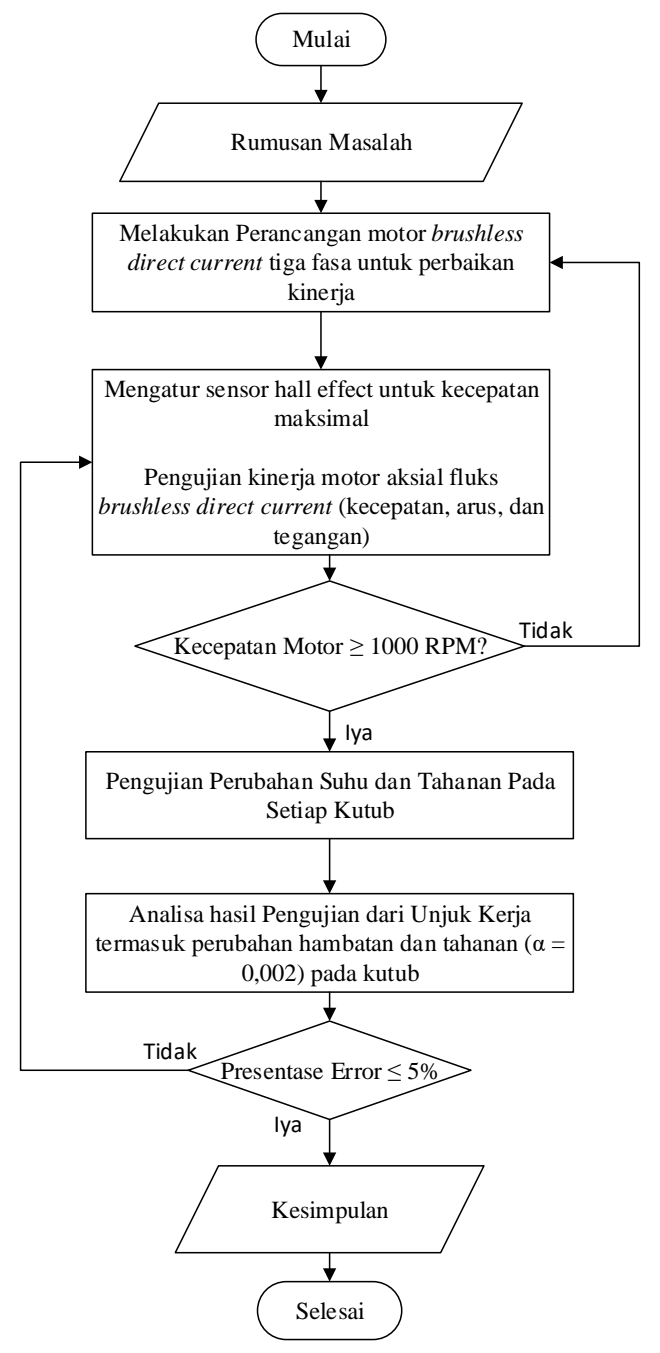

Gambar 1. Flowchart Tahap Penelitian

Pada gambar 1 dijelaskan mengenai flowchart penelitian dimana dapat diawali dari inisialisasi dalam penentuan parameter kecepatan diatas 1000 RPM. Selanjutnya dilakukan perancangan desain motor Axial Flux Brushless Direct Current Tiga Fasa Stator Ganda sebagai bentuk perbaikan kinerja pada motor. 1000 RPM didapat dari rumus Kecepatan. Selanjutnya mengatur sensor hall effect untuk mengatur kecepatan semaksimal mungkin.

Dilakukan pula bentuk pengujian pada kinerja motor untuk mengetahui kecepatan arus maupun tegangan dan dilihat apakah sesuai dengan parameter. Jika didapatkan hasil yang tidak sesuai maka kembali lagi perancangan motor Axial Flux Brushless Direct Current tiga fasa stator ganda untuk dilakukan perbaikan kinerja kembali. Namun jika dianggap telah sesuai maka dilakukan pengujian terhadap perubahan suhu dan tahanan pada setiap kutub. Selanjutnya dilakukan analisa hasil pengujian terhadap hasil data yang telah didapatkan dan ditarik kesimpulan. Tahapan ini dilakukan sebanyak tiga kali pada setiap jenis kawat enamel.

\section{Blok Diagram Sistem}

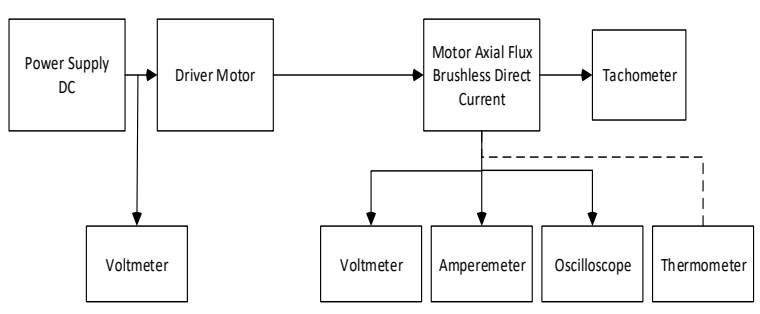

Gambar 2. Blok Diagram Sistem

Pada motor axial flux brushless direct current axial flux 3 fasa stator ganda ini menggunakan 8 buah magnet permanen yang diletakkan pada rotor dan dibagi berdasar sudut secara seimbang. Sedangkan untuk stator yang digunakan yaitu stator ganda yang terletak pada sisi kanan dan kiri rotor dengan 6 buah kumparan pada setiap statornya.

\section{HASIL DAN PEMBAHASAN}

Hasil unjuk kerja motor Brushles Direct Current Axial Fllx 3 Fasa Stator Ganda Dengan Kawat Enamel Hellenic.

Dalam Penggunaan kawat pertama yaitu menggunakan kawat Hellenic dimana pada kawat tersebut disesuaikan dengan perencanaan pembuatan kutubnya sejumlah 12 buah yang terbagi atas 6 buah kutub di posisi stator sebelah kanan (R) dan 6 buah stator yang berada di sebelah kiri (L). Setelah itu dilakukan paralel pada kedua stator sehingga dapat memenuhi konfigurasi pada motor.

Dalam pengambilan data didapatkan dengan menggunakan beberapa alat dimana menggunakan voltmeter sebagai pengukur tegangan pada antar fasa, ampere meter, tacho meter sebagai pengukur untuk kecepatan yang terdapat pada masukan motor. Hasilnya dapat dilihat pada tabel 4.1 berikut. 
Tabel 2. Hasil Pengukuran Unjuk Kerja Motor BLDC Dengan Menggunakan Kawat Enamel Hellenic.

\begin{tabular}{|c|c|c|c|c|c|}
\hline \multirow{2}{*}{$\begin{array}{c}\text { Uji } \\
\text { Ke }\end{array}$} & \multicolumn{3}{|c|}{ Tegangan (V) } & \multirow{2}{*}{ Ao (I) } & Kecepatan \\
\cline { 2 - 5 } & R-S & R-T & S-T & & \\
\hline 1 & 17,23 & 16,08 & 15,98 & 1,226 & 1023 \\
\hline 2 & 16,9 & 17,4 & 17,3 & 1,259 & 1043 \\
\hline 3 & 16,4 & 16,57 & 16,59 & 1,287 & 1046 \\
\hline
\end{tabular}

Sehingga pada pengujian ini dapat diketahui pada proses uji kedua mengalami beberapa peningkatan dari sisi tegangan, arus dan kecepatan namun ketika dilakukan pengujian yang ketiga kali, hasilnya sama tidak jauh beda dengan hasil pada pengujian kedua. setelah itu ketika motor selesai dilakukan pengujian maka motor dimatikan dan diukur berapa tahanan sebelum dan setelah dilakukan pengujian. Hasil tersebut dapat dilihat pada tabel 3 berikut.

Tabel 3.Hasil Pengukuran Uji Tahanan Kawat Enamel Hellenic 5 Menit Kerja.

\begin{tabular}{|c|c|c|c|c|}
\hline \multirow{2}{*}{$\begin{array}{c}\text { Nama } \\
\text { Kutub }\end{array}$} & \multicolumn{4}{|c|}{ Uji Ke } \\
\cline { 2 - 5 } & $\mathbf{0}$ & $\mathbf{1}$ & $\mathbf{2}$ & $\mathbf{3}$ \\
\hline R1 & $31,11^{\circ} \mathrm{C}$ & $40,56^{\circ} \mathrm{C}$ & $46,67 \mathrm{C}$ & $51,67 \mathrm{C}$ \\
\hline R2 & $31,11^{\circ} \mathrm{C}$ & $37,78^{\circ} \mathrm{C}$ & $40,56 \mathrm{C}$ & $40,00^{\circ} \mathrm{C}$ \\
\hline R3 & $31,11^{\circ} \mathrm{C}$ & $38,33^{\circ} \mathrm{C}$ & $40,566^{\circ} \mathrm{C}$ & $46,11^{\circ} \mathrm{C}$ \\
\hline R4 & $31,11^{\circ} \mathrm{C}$ & $42,78^{\circ} \mathrm{C}$ & $41,11^{\circ} \mathrm{C}$ & $47,22^{\circ} \mathrm{C}$ \\
\hline R5 & $31,11^{\circ} \mathrm{C}$ & $44,44^{\circ} \mathrm{C}$ & $45,00^{\circ} \mathrm{C}$ & $47,78^{\circ} \mathrm{C}$ \\
\hline R6 & $31,11^{\circ} \mathrm{C}$ & $43,89^{\circ} \mathrm{C}$ & $41,11^{\circ} \mathrm{C}$ & $49,44^{\circ} \mathrm{C}$ \\
\hline L1 & $31,11^{\circ} \mathrm{C}$ & $40,56^{\circ} \mathrm{C}$ & $42,22^{\circ} \mathrm{C}$ & $47,78^{\circ} \mathrm{C}$ \\
\hline L2 & $31,11^{\circ} \mathrm{C}$ & $40,56^{\circ} \mathrm{C}$ & $42,78^{\circ} \mathrm{C}$ & $47,78^{\circ} \mathrm{C}$ \\
\hline L3 & $31,11^{\circ} \mathrm{C}$ & $37,22^{\circ} \mathrm{C}$ & $44,44^{\circ} \mathrm{C}$ & $46,67 \mathrm{C}$ \\
\hline L4 & $31,11^{\circ} \mathrm{C}$ & $35,56^{\circ} \mathrm{C}$ & $41,67 \mathrm{C}$ & $42,22^{\circ} \mathrm{C}$ \\
\hline L5 & $31,11^{\circ} \mathrm{C}$ & $40,56^{\circ} \mathrm{C}$ & $45,00^{\circ} \mathrm{C}$ & $43,33^{\circ} \mathrm{C}$ \\
\hline L6 & $31,11^{\circ} \mathrm{C}$ & $40,56^{\circ} \mathrm{C}$ & $39,44^{\circ} \mathrm{C}$ & $39,44^{\circ} \mathrm{C}$ \\
\hline
\end{tabular}

Selanjutnya dicatat pula hasil dari pengukuran suhu menggunakan IR Thermo dengan menembakkan laser pada pada masing masing kutub sehingga diketahui nilai dari suhu yang saat enamel selesai bekerja sehingga didapatkan hasil dalam tabel 4.3 berikut.
Tabel 4 Hasil Pengukuran Uji Suhu Kawat Enamel Hellenic dengan selang waktu 5 Menit Kerja

\begin{tabular}{|c|c|c|c|c|}
\hline \multirow{2}{*}{$\begin{array}{l}\text { Nama } \\
\text { Kutub }\end{array}$} & \multicolumn{4}{|c|}{ Uji Ke } \\
\hline & 0 & 1 & 2 & 3 \\
\hline $\mathrm{R} 1$ & $31,11^{\circ} \mathrm{C}$ & $40,56^{\circ} \mathrm{C}$ & $46,67 \mathrm{C}$ & $51,67 \mathrm{C}$ \\
\hline $\mathrm{R} 2$ & $31,11^{\circ} \mathrm{C}$ & $37,78^{\circ} \mathrm{C}$ & $40,56^{\circ} \mathrm{C}$ & $40,00^{\circ} \mathrm{C}$ \\
\hline R3 & $31,11^{\circ} \mathrm{C}$ & $38,33^{\circ} \mathrm{C}$ & $40,56^{\circ} \mathrm{C}$ & $46,11^{\circ} \mathrm{C}$ \\
\hline $\mathrm{R} 4$ & $31,11^{\circ} \mathrm{C}$ & $42,78^{\circ} \mathrm{C}$ & $41,11^{\circ} \mathrm{C}$ & $47,22^{\circ} \mathrm{C}$ \\
\hline R5 & $31,11^{\circ} \mathrm{C}$ & $44,44^{\circ} \mathrm{C}$ & $45,00^{\circ} \mathrm{C}$ & $47,78^{\circ} \mathrm{C}$ \\
\hline $\mathrm{R} 6$ & $31,11^{\circ} \mathrm{C}$ & $43,89^{\circ} \mathrm{C}$ & $41,11^{\circ} \mathrm{C}$ & $49,44^{\circ} \mathrm{C}$ \\
\hline L1 & $31,11^{\circ} \mathrm{C}$ & $40,56^{\circ} \mathrm{C}$ & $42,22^{\circ} \mathrm{C}$ & $47,78^{\circ} \mathrm{C}$ \\
\hline L2 & $31,11^{\circ} \mathrm{C}$ & $40,56^{\circ} \mathrm{C}$ & $42,78^{\circ} \mathrm{C}$ & $47,78^{\circ} \mathrm{C}$ \\
\hline L3 & $31,11^{\circ} \mathrm{C}$ & $37,22^{\circ} \mathrm{C}$ & $44,44^{\circ} \mathrm{C}$ & $46,67 \mathrm{C}$ \\
\hline L4 & $31,11^{\circ} \mathrm{C}$ & $35,56^{\circ} \mathrm{C}$ & $41,67 \mathrm{C}$ & $42,22^{\circ} \mathrm{C}$ \\
\hline L5 & $31,11^{\circ} \mathrm{C}$ & $40,56^{\circ} \mathrm{C}$ & $45,00^{\circ} \mathrm{C}$ & $43,33^{\circ} \mathrm{C}$ \\
\hline L6 & $31,11^{\circ} \mathrm{C}$ & $40,56^{\circ} \mathrm{C}$ & $39,44^{\circ} \mathrm{C}$ & $39,44^{\circ} \mathrm{C}$ \\
\hline
\end{tabular}

a. Perhitungan Kecepatan Output Pada Motor Brushless Direct Current 3 Fasa Stator Ganda.

Pada perhitungan kecepatan dilakukan dengan melakukan perhitungan medan magnet antara kutub dengan pole. Dimana pada perhitungan ini dilakukan dengan melakukan perkalian $\sqrt{3}$ dengan arus keluaran $(I a)$, tegangan keluaran motor $(E a)$ dan 60 dan dibagi dengan $2 \pi \mathrm{T}$ sebagai rumus dari motor tiga fasa. $T$ merupakan torsi motor Brushless Direct Current yang didapatkan dari perhitungan torsi dari kuat gaya tarik menarik atau $T=F * R$. Dimana pada $\mathrm{F}$ merupakan nilai kuat gaya tarik menarik yang didapatkan dengan $F=k \frac{m 1 . m 2}{r^{2}}$. k pada rumus tersebut merupakan sebuah konstanta atau tetapan yang bernilai $10^{-7}$. Selanjutnya dikalikan dengan kuat medan pada magnet permanen dan kuat medan pada kumparan sehingga muncul gaya tarik menarik. Sedangkan untuk nilai dari $\mathrm{R}$ merupakan jari jari rotor. Sehingga dapat dilihat hasil error nilai antara hasil pengukuran kecepatan dan hasil perhitungan pada tabel berikut. 
Tabel 5. Perhitungan Kecepatan Putaran Motor Brushless Direct Current 3 Phase Stator Ganda

\begin{tabular}{|c|c|c|c|c|c|}
\hline $\begin{array}{c}\text { Tegang } \\
\text { an } \\
\begin{array}{c}\text { Sumbe } \\
\text { r (V) }\end{array}\end{array}$ & $\begin{array}{c}\text { Tegang } \\
\text { an } \\
\text { Motor } \\
\text { (V) }\end{array}$ & $\begin{array}{c}\text { Aru } \\
\text { s } \\
\text { Mot } \\
\text { or } \\
(\mathrm{I})\end{array}$ & $\begin{array}{c}\text { Kecepat } \\
\text { an Ukur } \\
\text { (RPM) }\end{array}$ & $\begin{array}{c}\text { Perhitun } \\
\text { gan } \\
\text { Kecepat } \\
\text { an } \\
\text { (RPM) }\end{array}$ & E\% \\
\hline \multirow{2}{*}{24} & 16,43 & 1,23 & 1023 & 1024,30 & $\begin{array}{c}0,1 \\
27\end{array}$ \\
\cline { 2 - 6 } & 16,8 & 1,26 & 1043 & 1047,36 & $\begin{array}{c}0,4 \\
18\end{array}$ \\
\cline { 2 - 6 } & 16,52 & 1,29 & 1046 & 1029,91 & $\begin{array}{c}1,5 \\
39\end{array}$ \\
\hline
\end{tabular}

b. Perhitungan Torsi dan Gaya Output Putar Motor Pada Motor Brushless Direct Current 3 Fasa Stator Ganda.

Pada perhitungan torsi didapat dengan mengalikan akar 3 dengan arus output (la), Tegangan Output (Ea), dan dikalikan 60. Setelah itu dibagi dengan $2 \pi$ dikali dengan Rpm. Sedangkan untuk Gaya sendiri dilakukan dengan membandingkan hasil pegaya dari pengukuran dan hasil murni dari teori.

Tabel 6. Hasil Perhitungan Gaya dan Torsi Motor Brushless Direct Current 3 Fasa Stator Ganda dengan Kawat Enamel Hellenic.

\begin{tabular}{|c|c|c|c|c|c|c|}
\hline $\begin{array}{l}\text { Teg } \\
\text { anga } \\
\mathrm{n}(\mathrm{V})\end{array}$ & $\begin{array}{c}\text { Aru } \\
\text { S } \\
\text { (A) }\end{array}$ & $\begin{array}{c}\text { Kecep } \\
\text { atan } \\
(\mathrm{rpm})\end{array}$ & $\begin{array}{c}\text { Tors } \\
\text { i } \\
(\mathrm{Nm} \\
)\end{array}$ & $\begin{array}{c}\text { Gay } \\
a \\
\left(F^{\prime}\right)\end{array}$ & $\begin{array}{l}\text { Per. } \\
\text { Torsi } \\
(\mathrm{Nm})\end{array}$ & $\mathrm{E} \%$ \\
\hline 16,43 & $\begin{array}{l}1,2 \\
26 \\
\end{array}$ & 1023 & $\begin{array}{c}0,32 \\
58\end{array}$ & $\begin{array}{l}9,0 \\
397\end{array}$ & 0,3254 & $\begin{array}{c}0,1 \\
265 \\
38 \\
\end{array}$ \\
\hline 16,8 & $\begin{array}{l}1,2 \\
59\end{array}$ & 1043 & $\begin{array}{c}0,33 \\
56\end{array}$ & $\begin{array}{l}9,2 \\
830\end{array}$ & 0,3342 & $\begin{array}{c}0,4 \\
165 \\
75\end{array}$ \\
\hline 16,52 & $\begin{array}{l}1,2 \\
87 \\
\end{array}$ & 1046 & $\begin{array}{c}0,33 \\
64 \\
\end{array}$ & $\begin{array}{r}9,4 \\
894 \\
\end{array}$ & 0,3416 & $\begin{array}{c}1,5 \\
625 \\
68 \\
\end{array}$ \\
\hline
\end{tabular}

Pada hasil pengukuran didapatkan dari pembagian antara rumus dan jari jari penampang sedangkan untuk dari rumus teori didapatkan dari $\mathrm{k}\left(10^{-7}\right)$ dikalikan dengan kuat kutub magnet permanen $\left(m_{1}\right)$, dan kuat kutub magnet kumparan $\left(m_{2}\right)$. Setelah itu dibagi dengan kuadran jarak atau gap antara magnet permanen dan besi kumparan ( $r$ ). Sehingga dapat dilihat hasil torsi dan gaya dapat dilihat dalam tabel berikut.

Hasil dari perbandingan kedua perhitungan torsi tersebut tidak jauh berbeda dimana dapat dilihat melalui error persen atau selisih antara nilai keduanya yang tidak jauh berbeda. Sebagai contoh dapat dilihat pada pengujian yang pertama dimana didapatkan torsi 0,325
$\mathrm{Nm}$ dalam perhitungan melalui nilai tegangan maupun arus motor. Sedangkan pada torsi dengan rumus pembanding diketahui 0,3254 $\mathrm{Nm}$. Sehingga dalam perbandingan antar keduanya hanya terpaut 0,126 \%. Perbandingan antara kedua perhitungan torsi dapat dilihat pada grafik berikut.

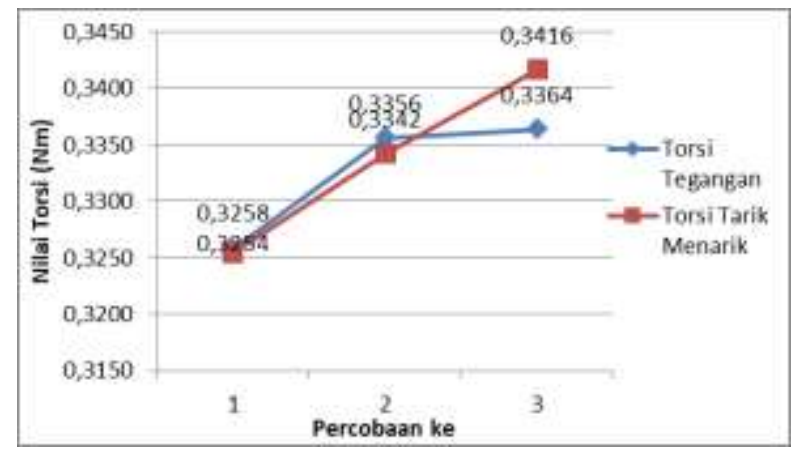

Gambar 3. Grafik kenaikan torsi pada nilai kondisi pengujian berulang menggunakan kawat hellenic

\section{c. Perhitungan Tahanan Terhadap Suhu Pada Kutub Motor Brushless Direct Current 3 Fasa Stator Ganda}

Perhitungan tahanan kumparan terhadap suhu dilakukan untuk mengetahui seberapa efisiensi tahanan terhadap suhu yang timbul akibat kerja motor. untuk nilai tahanan yang dihitung pada kutub tersebut dilakukan dengan membandingkan hasil dari pengujian dan hasil dari teori yang didapat dengan jurnal terkait mengenai konstanta kawat enamel yaitu sebesar $0,002 \Omega$ sehingga untuk membandingkan kedua hasil tersebut digunakan rumus $R T=R_{0}(1+\alpha . \Delta t)$. Dimana RT yaitu tahanan setelah dilakukan kerja motor, $R_{0}$ yaitu sebagai tahanan sebelum motor bekerja, $\alpha$ merupakan konstanta panas dari kawat enamel, dan $\Delta \mathrm{t}$ merupakan selisih suhu sebelum dan sesudah kerja motor. sehingga untuk data hasil perhitungan dapat pada gambar 4 berikut.

Dapat dilihat bahwa kenaikan terbesar terjadi saat pengujian kedua dimana kenaikan terbesar terjadi hingga 3,3\% pada kawat enamel R4. Namun pada saat dilakukan pengujian kembali setelah kerja 5 menit maka sebagian besar error persen pada masing-masing kutub dengan kawat enamel Hellenic mengalami penurunan nilai error persen. Hal ini juga dipengaruhi oleh suhu dan resistansi mula pada enamel. 


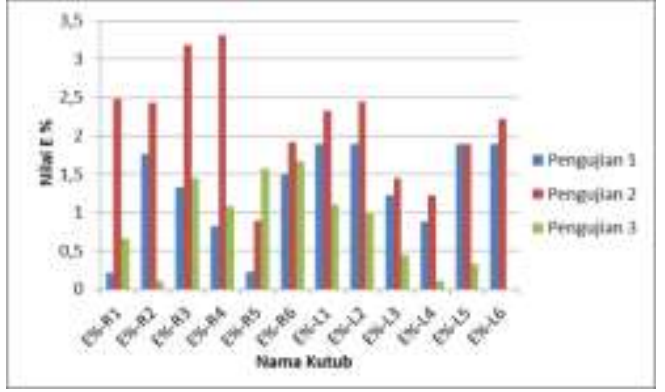

Gambar 4. Grafik Error Persen Perbandingan Nilai Hasil Pengukuran Dengan Nilai Hasil Perhitungan Pada Enamel Hellenic.

\section{Hasil unjuk kerja motor Brushles Direct Current Axial Fllx 3 Fasa Stator Ganda Dengan Kawat Enamel Supreme.}

Pada kawat enamel yang kedua ini menggunakan kawat enamel tipe supreme yang tersedia banyak di Indonesia dan sudah menyebar. Dimana pada kawat enamel ini memiliki bentuk dan ukuran yang sama. Panjang dari kawat enamel yang digunakan juga sama dengan kawat enamel yang sebelumnya yaitu $13,5 \mathrm{~m}$ pada diameter kawat enamel $0,3 \mathrm{~mm}$. Jika ditinjau dari harga, kawat enamel ini terbilang murah jika dibandingkan dengan kawat hellenic. Selain itu untuk bentuk fisik pada kawat enamel ini (kawat enamel supreme) memiliki bentuk fisik yang agak berbeda yaitu lebih sulit dilekukkan daripada kawat enamel tipe Hellenic.

Tabel 7 Hasil Pengukuran Unjuk kerja Motor Brushless Direct Current Dengan Menggunakan Kawat Enamel Supreme.

\begin{tabular}{|c|c|c|c|c|c|}
\hline \multirow{2}{*}{ Uji } & \multicolumn{3}{|c|}{ Tegangan (V) } & \multirow{2}{*}{ Ao(I) } & \multirow{2}{*}{ RPM } \\
\cline { 2 - 5 } & R-S & R-T & S-T & & \\
\hline 1 & 16,8 & 16,5 & 17,8 & 1,25 & 1378 \\
\hline 2 & 17,01 & 16,6 & 17,8 & 1,22 & 1387 \\
\hline 3 & 16,6 & 16,5 & 17,6 & 1,225 & 1388 \\
\hline
\end{tabular}

Selain data yang sudah didapatkan diatas pada masing-masing bentuk pengujian, didapatkan pula hasil nilai data mengenai uji kenaikan tahanan terhadap suhu. Pengujian ini dilakukan sesaat setelah motor telah berhenti bekerja. Hasil nilai kenaikan resistansi juga bervariasi seiring dengan kenaikan suhu ruang dan nilai koefisien bahan enamel yang digunakan. Hasil dari nilai pengukuran dapat dilihat pada tabel berikut.
Tabel 8 Hasil Pengukuran Uji Tahanan Kawat Enamel Hellenic 5 Menit Kerja

\begin{tabular}{|c|c|c|c|c|}
\hline \multirow{2}{*}{ Nama Kutub } & \multicolumn{4}{|c|}{ Uji Ke } \\
\cline { 2 - 5 } & $\mathbf{0}$ & $\mathbf{1}$ & $\mathbf{2}$ & $\mathbf{3}$ \\
\hline $\mathrm{R} 1$ & $2,82 \Omega$ & $2,86 \Omega$ & $2,85 \Omega$ & $2,86 \Omega$ \\
\hline $\mathrm{R} 2$ & $2,79 \Omega$ & $2,85 \Omega$ & $2,88 \Omega$ & $2,9 \Omega$ \\
\hline $\mathrm{R} 3$ & $2,82 \Omega$ & $2,85 \Omega$ & $2,86 \Omega$ & $2,87 \Omega$ \\
\hline R4 & $2,75 \Omega$ & $2,86 \Omega$ & $2,86 \Omega$ & $2,86 \Omega$ \\
\hline R5 & $2,77 \Omega$ & $2,81 \Omega$ & $2,8 \Omega$ & $2,8 \Omega$ \\
\hline R6 & $2,76 \Omega$ & $2,86 \Omega$ & $2,83 \Omega$ & $2,85 \Omega$ \\
\hline L1 & $2,85 \Omega$ & $2,93 \Omega$ & $2,99 \Omega$ & $2,97 \Omega$ \\
\hline L2 & $2,85 \Omega$ & $2,89 \Omega$ & $2,95 \Omega$ & $3,03 \Omega$ \\
\hline L3 & $2,8 \Omega$ & $2,92 \Omega$ & $2,99 \Omega$ & $2,95 \Omega$ \\
\hline L4 & $2,84 \Omega$ & $2,93 \Omega$ & $2,95 \Omega$ & $2,95 \Omega$ \\
\hline L5 & $2,86 \Omega$ & $2,95 \Omega$ & $2,99 \Omega$ & $2,98 \Omega$ \\
\hline L6 & $2,85 \Omega$ & $2,89 \Omega$ & $2,9 \Omega$ & $2,9 \Omega$ \\
\hline
\end{tabular}

Dilakukan pula pengujian dengan menggunakan bentuk pengujian suhu. Hal ini dilakukan guna mengetahui pula reaksi kenaikan suhu yang terjadi pada kawat enamel. Setiap data tetap akan diambil pada seluruh kutub kumparan dimana pada kutub tersebut dilihat dengan sensor suhu pada kumparan. Setelah itu dapat dilakukan mencatat nilai yang tercantum pada alat pengukur suhu tersebut dan ditulis dalam tabel berikut.

Tabel 9. Hasil Pengukuran Uji Suhu Kawat Enamel Hellenic dengan selang waktu 5 Menit Kerja.

\begin{tabular}{|c|c|c|c|c|}
\hline \multirow{2}{*}{$\begin{array}{c}\text { Nama } \\
\text { Kutub }\end{array}$} & \multicolumn{4}{|c|}{ Uji Ke } \\
\cline { 2 - 5 } & 0 & 1 & 2 & 3 \\
\hline R1 & $31,11^{\circ} \mathrm{C}$ & $41,67 \mathrm{C}$ & $44,44^{\circ} \mathrm{C}$ & $47,22^{\circ} \mathrm{C}$ \\
\hline R2 & $31,11^{\circ} \mathrm{C}$ & $45,56^{\circ} \mathrm{C}$ & $42,78^{\circ} \mathrm{C}$ & $47,22^{\circ} \mathrm{C}$ \\
\hline R3 & $31,11^{\circ} \mathrm{C}$ & $39,44^{\circ} \mathrm{C}$ & $38,89^{\circ} \mathrm{C}$ & $38,33^{\circ} \mathrm{C}$ \\
\hline R4 & $31,11^{\circ} \mathrm{C}$ & $42,22^{\circ} \mathrm{C}$ & $46,11^{\circ} \mathrm{C}$ & $42,22^{\circ} \mathrm{C}$ \\
\hline R5 & $31,11^{\circ} \mathrm{C}$ & $41,11^{\circ} \mathrm{C}$ & $43,89^{\circ} \mathrm{C}$ & $47,22^{\circ} \mathrm{C}$ \\
\hline R6 & $31,11^{\circ} \mathrm{C}$ & $40,56^{\circ} \mathrm{C}$ & $45,56^{\circ} \mathrm{C}$ & $45,00^{\circ} \mathrm{C}$ \\
\hline L1 & $31,11^{\circ} \mathrm{C}$ & $37,78^{\circ} \mathrm{C}$ & $46,67 \mathrm{C}$ & $45,56^{\circ} \mathrm{C}$ \\
\hline L2 & $31,11^{\circ} \mathrm{C}$ & $39,44^{\circ} \mathrm{C}$ & $43,89^{\circ} \mathrm{C}$ & $45,00^{\circ} \mathrm{C}$ \\
\hline L3 & $31,11^{\circ} \mathrm{C}$ & $44,44^{\circ} \mathrm{C}$ & $47,78^{\circ} \mathrm{C}$ & $48,89^{\circ} \mathrm{C}$ \\
\hline L4 & $31,11^{\circ} \mathrm{C}$ & $37,22^{\circ} \mathrm{C}$ & $48,89^{\circ} \mathrm{C}$ & $48,89^{\circ} \mathrm{C}$ \\
\hline L5 & $31,11^{\circ} \mathrm{C}$ & $44,44^{\circ} \mathrm{C}$ & $42,22^{\circ} \mathrm{C}$ & $43,33^{\circ} \mathrm{C}$ \\
\hline L6 & $31,11^{\circ} \mathrm{C}$ & $42,78^{\circ} \mathrm{C}$ & $46,11^{\circ} \mathrm{C}$ & $47,78^{\circ} \mathrm{C}$ \\
\hline
\end{tabular}


a. Perhitungan Kecepatan Output Pada Motor Brushless Direct Current 3 Fasa Stator Ganda.

Pada perhitungan kecepatan ini masih sama yaitu dilakukan dengan melakukan perhitungan medan magnet antara kutub dengan pole. Dimana pada perhitungan ini dilakukan dengan melakukan perkalian $\sqrt{3}$ dengan arus keluaran $(I a)$, tegangan keluaran motor $(E a)$ dan 60 dan dibagi dengan $2 \pi T$ sebagai rumus dari motor tiga fasa. T merupakan torsi motor. Sehingga dapat dilihat juga hasil error nilai antara hasil pengukuran kecepatan dan hasil perhitungan pada tabel berikut.

Tabel 10. Pengujian Kecepatan Putaran Motor Brushless Direct Current 3 Phase Stator Ganda

\begin{tabular}{|c|c|c|c|c|c|}
\hline $\begin{array}{c}\text { Tegang } \\
\text { an } \\
\begin{array}{c}\text { Sumber } \\
\text { (V) }\end{array}\end{array}$ & $\begin{array}{c}\text { Tegan } \\
\text { gan } \\
\text { Motor } \\
\text { (V) }\end{array}$ & $\begin{array}{c}\text { Ar } \\
\text { us } \\
(I)\end{array}$ & $\begin{array}{c}\text { Kecepat } \\
\text { an Ukur } \\
\text { (RPM) }\end{array}$ & $\begin{array}{c}\text { Perhitu } \\
\text { ngan } \\
\text { Kecepa } \\
\text { tan } \\
\text { (RPM) }\end{array}$ & E\% \\
\hline \multirow{2}{*}{24} & 17,03 & $\begin{array}{c}1, \\
25\end{array}$ & 1378 & 1323,45 & 3,96 \\
\cline { 2 - 6 } & 17,14 & $\begin{array}{c}1, \\
22\end{array}$ & 1387 & 1331,48 & 4,00 \\
\cline { 2 - 6 } & 16,90 & $\begin{array}{c}1, \\
23\end{array}$ & 1388 & 1313,09 & 5,40 \\
\hline
\end{tabular}

b. Perhitungan Torsi Output Pada Motor Brushless Direct Current 3 Fasa Stator Ganda.

Tabel 10. Hasil Perhitungan Gaya dan Torsi Motor Brushless Direct Current 3 Fasa Stator Ganda dengan Kawat Enamel Supreme.

\begin{tabular}{|c|c|c|c|c|c|c|}
\hline $\begin{array}{c}\text { Tegan } \\
\text { gan } \\
(\mathrm{V})\end{array}$ & $\begin{array}{c}\text { Aru } \\
\mathrm{s} \\
(\mathrm{A})\end{array}$ & $\begin{array}{c}\text { Kecepa } \\
\text { tan } \\
(\mathrm{rpm})\end{array}$ & $\begin{array}{c}\text { Torsi } \\
(\mathrm{Nm})\end{array}$ & $\begin{array}{c}\text { Gay } \\
\text { a } \\
\left(\mathrm{F}^{\prime}\right)\end{array}$ & $\begin{array}{c}\text { Per. } \\
\text { Torsi } \\
(\mathrm{Nm})\end{array}$ & $\begin{array}{c}\mathrm{E} \\
\%\end{array}$ \\
\hline $\begin{array}{c}17,03 \\
3\end{array}$ & $\begin{array}{c}1,2 \\
5\end{array}$ & 1378 & $\begin{array}{c}0,25 \\
57\end{array}$ & $\begin{array}{c}7,39 \\
52\end{array}$ & 0,2662 & $\begin{array}{c}3,9 \\
58 \\
8\end{array}$ \\
\hline $\begin{array}{c}17,13 \\
7\end{array}$ & $\begin{array}{c}1,2 \\
2\end{array}$ & 1387 & $\begin{array}{c}0,24 \\
94\end{array}$ & $\begin{array}{c}7,21 \\
78\end{array}$ & 0,2598 & $\begin{array}{c}4,0 \\
03 \\
1\end{array}$ \\
\hline 16,9 & $\begin{array}{c}1,2 \\
25\end{array}$ & 1388 & $\begin{array}{c}0,24 \\
68\end{array}$ & $\begin{array}{c}7,24 \\
73\end{array}$ & 0,2609 & $\begin{array}{c}5,3 \\
97 \\
1\end{array}$ \\
\hline
\end{tabular}

Dari tabel 10 tersebut dapat dilihat hasil dari perbandingan kedua perhitungan torsi tersebut tidak jauh berbeda dimana dapat dilihat melalui error persen atau selisih antara nilai keduanya yang tidak jauh berbeda. Sebagai contoh dapat dilihat pada pengujian yang pertama dimana didapatkan torsi 0,2557 $\mathrm{Nm}$ dalam perhitungan melalui nilai tegangan maupun arus motor. Sedangkan pada torsi dengan rumus pembanding diketahui 0,2662 $\mathrm{Nm}$.Perbandingan antara kedua perhitungan torsi dapat dilihat pada grafik berikut.

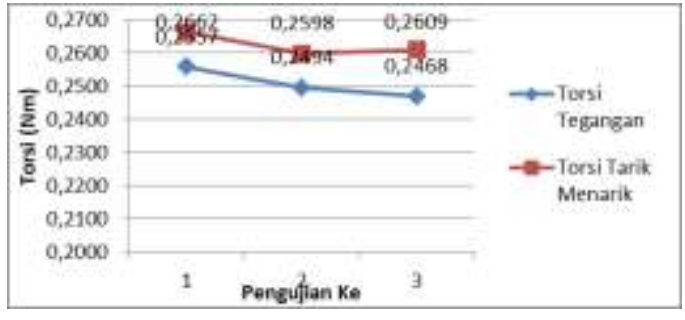

Gambar 4. Grafik kenaikan torsi pada nilai kondisi pengujian berulang menggunakan kawat Supreme

Pada gambar 4tersebut menjelaskan mengenai perbedaan pada nilai torsi diatas sangatlah berbanding lurus antara nilai torsi dari hasil ukur dan nilai torsi yang didapat dari hasil gaya tarik menarik. Dapat dilihat pada torsi tegangan, keadaaan grafik terus mengalami penurunan hingga pengujian kedua. Namun pada pengujian yang ketiga, kenaikan pada nilai torsi cukup rendah atau sama dan stabil dalam siklus grafik.

c. Perhitungan Tahanan Terhadap Suhu Pada Kutub Motor Brushless Direct Current 3 Fasa Stator Ganda.

Perhitungan tahanan kumparan terhadap suhu masih sama yaitu dilakukan untuk mengetahui seberapa efisiensi tahanan terhadap suhu yang timbul akibat kerja motor. untuk nilai tahanan yang dihitung pada kutub tersebut dilakukan dengan membandingkan hasil dari pengujian dan hasil dari teori yang didapat dengan jurnal terkait mengenai konstanta kawat enamel yaitu sebesar 0,002 $\Omega$ sehingga untuk membandingkan kedua hasil tersebut digunakan rumus $R T=R \_0$ $(1+\alpha \cdot \Delta t)$.

Dapat dijelaskan bahwa kenaikan yang terjadi pada kawat enamel tersebut naik secara berkala. Kenaikan ini terjadi tidak begitu signifikan, dimana jika dilihat berdasarkan contoh dari data akan meningkat pada pengujian yang kedua sedangkan ketika dilakukan bentuk pengujian yang ketiga maka hambatan kembali menurun. Namun adapula yang mengalami penurunan secara bertahap sehingga dapat diidentifikasi bahwa perubahan yang terjadi tidak sama antara satu dan yang lainnya pada posisi kawat enamel yang berbeda.Bbedasarkan data yang digunakan tersebut sesuai dengan nilai kenaikan suhu pada masing masing kumparan. 


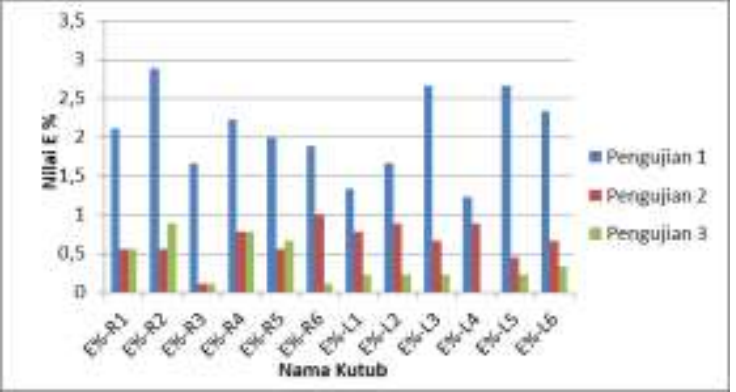

Gambar 5. Grafik Error Persen Perbandingan Nilai Hasil Pengukuran Dengan Nilai Hasil Perhitungan Pada Enamel Supreme.

Pada gambar 4.10 grafik error persen perbandingan nilai hasil pengukuran dengan nilai hasil perhitungan pada kawat enamel supreme dapat dilihat bahwa error persen mengalami kenaikan yang tinggi pada pengujian yang pertama. Namun setelah dilakukan pengujian kembali pada pengujian yang kedua, error persen turun secara signifikan hingga mencapai $0,5 \%$.

\section{Perbandingan Unjuk Kerja Motor Brushless Direct Current 3 Fasa Stator Ganda Terhadap Perbedaan Kawat Enamel. \\ Perbandingan unjuk kerja pada motor} Brushless Direct Current 3 Fasa stator ganda ini dilakukan guna menemukan unjuk kerja yang lebih baik diantara kedua kawat enamel pembanding. Unjuk kerja disini meliputi kecepatan, torsi, maupun resistansi pada saat menggunakan kedua jenis kawat enamel. Hal ini berpengaruh terhadap keunggulan masing-masing kawat enamel.

a. Perbandingan Kecepatan Dalam Perbedaan Kawat Enamel Hellenic dan Kawat Enamel Supreme.

Perbandingan antara dua nilai kecepatan berpengaruh terhadap torsi dari masing-masing motor dengan kawat enamel yang berbeda. Perbandingan pada kecepatan dilakukan guna mencari kecepatan motor Brushless Direct Current 3 Fasa Stator Ganda yang terbaik.

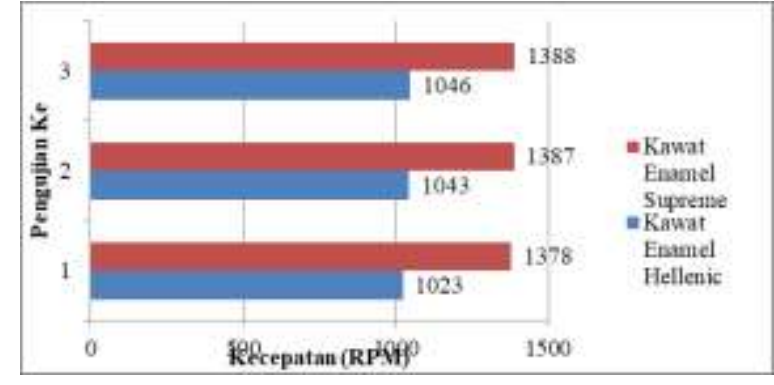

Gambar 6. Grafik Perbandingan Pengukuran Kecepatan Antara Kawat Jenis Hellenic dan Kawat Jenis Supreme.

Pada data di Gambar 6 tersebut dapat dilihat bahwa perbandingan antara kedua kawat enamel memiliki nilai kecepatan yang berbeda meskipun dengan panjang yang sama. Hal ini sebenarnya dipengaruhi dari arus yang mengalir pada kawat enamel tersebut. Selain itu nilai kecepatan juga tidak jauh dari nilai torsi. Antara nilai kecepatan dan nilai torsi sangatlah berkaitan dimana dapat diketahui bahwa nilai kecepatan berbanding terbalik dengan nilai torsi.

b. Perbandingan Torsi Dalam Perbedaan Kawat Enamel Supreme dan Kawat Enamel Hellenic.

Torsi dan kecepatan sangatlah saling berkaitan.Ketika dilakukan pembahasan perbandingan mengenai kecepatan maka tidak jauh juga dibahas mengenai torsi. Perbandingan antara dua hasil dari kawat enamel yang berbeda dengan perlakuan dan kondisi yang sama diharapkan guna mengetahui kawat enamel mana yang memiliki torsi lebih tinggi.

Data yang didapatkan dari tabel torsi pada kawat enamel Hellenic dan kawat enamel Supreme didapat berdasarkan torsi dari kecepatan yang didapat dan torsi dari gaya tarik menarik antar kedua kutub magnet. Sehingga dapat diketahui perhitungan dari segala bentuk dari pengujian torsi dapat dilakukan pengamatan. Berikut grafik perbandingan antara torsi berdasarkan kecepatan dari kawat jenis Hellenic dan kawat jenis Supreme. 


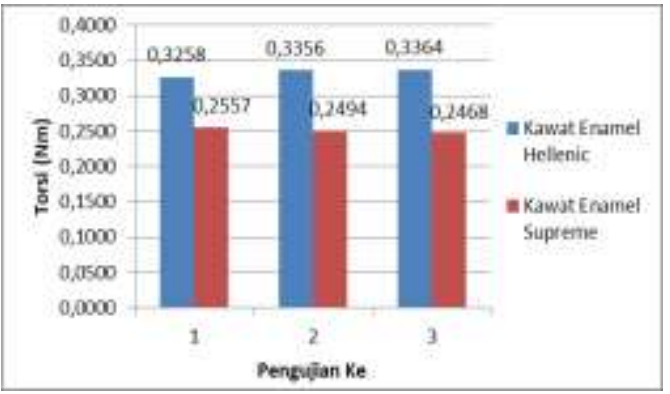

Gambar 7. Grafik Perbandingan Torsi Berdasarkan Kecepatan Pada Saat Motor Menggunakan Kawat Enamel Jenis Hellenic dan Kawat Enamel Jenis Supreme.

\section{c. Perbandingan Perubahan Resistansi} Dalam Perbedaan Kawat Enamel Supreme dan Kawat Enamel Hellenic. Dalam proses pengujian, dibandingkan kedua data dari masingmasing kawat enamel. Perbandingan dapat dilakukan dengan membandingkan grafik suhu dan perhitungan resistansi yang ada. Berikut grafik dari perbandingan perubahan resistansi terhadap perubahan suhu pada enamel hellenic dan enamel supreme pada masing-masing sisi dengan sampel kutub R1.

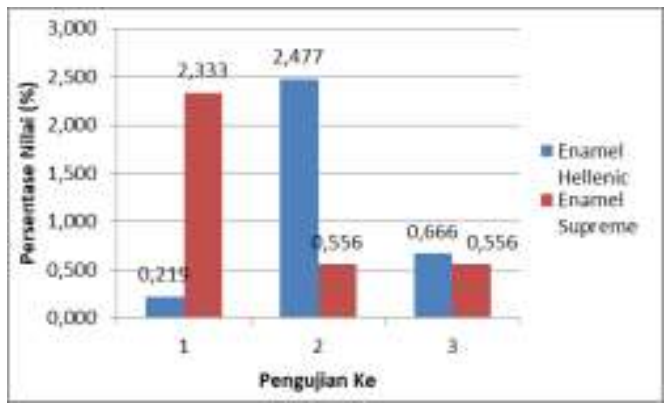

Gambar 8. Grafik Perbandingan Perubahan Resistansi Terhadap Perubahan Suhu Pada Enamel Hellenic dan Enamel Supreme Pada Kutub R1.

Dalam data tersebut dijelaskan bahwa perbedaan yang mendasar antara keduanya yaitu saat dilakukan pengujian pertama dan kedua.Kenaikan diantara data tersebut meningkat cukup tinggi. Dimana pada kawat enamel hellenic naik 20 RPM sedangkan pada kawat enamel Supreme naik 9 RPM. Untuk pengujian data yang kedua dan ketiga, kenaikan kecepatan hanya sedikit dan bahkan terbilang konstan. Dimana pada kenaikan yang terjadi pada kawat enamel Hellenic hanya mengalami kenaikan 3 RPM sedangkan untuk kawat Enamel Supreme hanya mengalami kenaikan 1 RPM.

\section{KESIMPULAN}

Perancangan yang dilakukan pada motor brushless direct current axial flux 3 fasa stator ganda dilakukan guna mendapatkan nilai torsi yang lebih tinggi $(\geq 0,3 \mathrm{Nm})$. Torsi dan kecepatan pada kedua jenis pengujian dengan panjang tiap kumparan yang sama dengan perbedaan kawat enamel memiliki hasil yang berbeda. Penggunaan kumparan kawat enamel hellenic memiliki torsi $0,334 \mathrm{Nm}$ yanglebih besar daripada kumparan yang menggunakan kawat enamel supreme dengan torsi $0,262 \mathrm{Nm}$. Perbedaan terjadi dikarenakan banyak faktor, termasuk kualitas kuat hantar pada kawat masing-masing jenis kawat enamel. Namun berbanding terbalik dengan nilai kecepatan dimana pada kawat enamel Supreme memiliki nilai kecepatan 300 RPM lebih tinggi. Dengan dilakukan pengujian secara berulang maka perubahan nilai resistansi pada setiap kawat enamel berbeda. Perbedaan perubahan terjadi secara signifikan terjadi pada pengujian pertama dan kedua. Dimana pada sampling data pada Gambar 9 dapat dilihat bahwa pada kawat enamel Hellenic terjadi kenaikan yang besar $(2,26 \%)$ saat pengujian yang kedua. Sedangkan untuk kawat enamel supreme terjadi penurunan error persen yang besar juga $(1,77 \%)$ dengan teori pada pengujian yang pertama. Hal ini dipengaruhi oleh kenaikan nilai suhu pada saat dilakukan pengujian berulang.

\section{DAFTAR PUSTAKA}

[1]. M. Hajid, "Buku Master Smp/Mts: Ringkasan Materi \& Kumpulan Rumus Lengkap", Penerbit mediapusindo,.2008

[2]. D. Halliday, R. Resnick, J. Walker, Fundamentals of Physics (edisi ke-6th). John Wiley \& Sons, Inc., 2001

[3]. Hamdani, Indrawan Andi W. 2015. "Programmable Logic Controller dan Scada Teori, Pemrograman dan Aplikasinya", Yogyakarta: Penerbit Deepublish

[4]. M. Aydin, S. Huang and T.A. Lipo, "Torque Quality and Comparison of Internal and External Rotor Axial Flux Surface Magnet Disc Machine", IEEE IECON2001, 27th Annual Conference of IEEE Industrial Electronics, Denver, CO, Nov 29-Dec, 2001

[5]. Maarten J. Kamper, dkk, "Analysis and Performance of Axial Flux Permanent- 
Magnet Machine With Air-Cored Nonoverlapping Concentrated Stator Windings", IEEE, 2004.

[6]. Othman Kashfi F.K.R.O, dkk, "Torque Constant Density in Different Type of Double Stator Permanent Magnet Brushless DC Motor", Electromagnetics Research, 2018.

[7]. Powers, J. M., Sakaguchi, R. L., \& Craig, R. G. (2012). Craig's restorative dental materials/edited by Ronald L. Sakaguchi, John M. Powers. Philadelphia, PA: Elsevier/Mosby.

[8]. Saleh, Anang, dkk. 2018. "Energi \& Elektrifikasi Pertanian”.Yogyakarta: Penerbit Deepublish.

[9]. Sinaga Nazaruddin, Sonda H. Marsono, "Pemilihan Kawat Enamel Untuk Pembuatan Solenoid Dinamometer Arus Eddy Dengan Torsi Maksimum 496 Nm", Jurnal Teknik Energi, 2013.

[10]. Simanjuntak, Vanessa Victor. "Analisis Dc Motor Pada Aplikasi Parkir Vertikal Otomatis Menggunakan RFID", Thesis Politeknik Negeri Sriwijaya, 2017. 